\title{
Nyai Madura: Representation of Female Religious Leaders in Contemporary Indonesia
}

Hasanatul Jannah ${ }^{+*}$ and Rachmah Ida ${ }^{i}$

\section{Abstract}

This paper examines the roles and position of female religious leaders in Madura Island, known as Nyai. Nyais are female religious leaders and are highly respected by the rural communities for not only being someone who is master in Islamic teachings, and her dakwah (outreach), but also being influential amongst the communities. Yet, the role and position of nyai in a patriarchal society of Madura are crucial in the sense that their dakwah and teachings have gradually become doctrine for female communities in the male-dominated environment. Particular nyais have demonstrated their determination in identity contestation and playing their agency role for their communities. Their popularity and growing followers have become a serious concern and criticism of some male religious leaders (known as kyai) in the Island. An ethnography study applied to observe the daily life of two female nyais in two regional districts of Madura, they are Nyai Sitti of Sampang and Nyai Dausy of Sumenep, and found that in the context of nyai's hierarchy in Madura, these two nyais have built what have created authority and represented their leadership positions on their social class. They are the central figures, where their popularity are shaped by their charisma, genealogy, and people's power. Indeed, they have reached the position of 'nyai rajheh' (great leader), which is a leading influential figure, especially for women in contemporary Madura Island.

Keywords: Nyai Madura, Female Religious Leader, a Muslim Leader, Women's Agency

\footnotetext{
${ }^{\dagger}$ Doctoral Student of Social Sciences, Airlangga University and Lecturer of Faculty of Ushuluddin and Dakwah, Surakarta State Islamic Institute, Indonesia

${ }^{*}$ Corresponding Author, Email: h4s.jannah@gmail.com

İ Lecturer of Faculty of Social and Political Sciences, Airlangga University, Indonesia

(C) 2019 Jannah and Ida. This is an Open Access article distributed under the terms of the Creative Commons Attribution License (http://creativecommons.org/licenses/by/2.0), which permits unrestricted use, distribution, and reproduction in any medium, provided the original work is properly cited.
} 


\section{Introduction}

Obedience and fanaticism towards religion have always been a part of Madurese (Kuntowijoyo, 1988). For the Madurese, Islam is a part of ethnical identity because of the way it is being perceived and continues to remain in Madura through the old belief-Islam is something like, "having shahada (Islamic confession) as a pillow, faith as a blanket, and Islam as an umbrella" (Rifai, 2007: 44). Indeed, Islam as a religion is ingrained in Madura people's soul (Ma'arif, 2015: 127), making Madurese male (kyai) and female religious figure (nyai) in a central and significant position. They are not just viewed as someone who teaches and practices religious values, but also as a subject that has the power of blessings.

For Madurese, it is imperative to keep the continuity of religious activities, which is not only kyai's (male leader) responsibility, but nyai (female leader) also has an obligation to it. As an elite holding a respectable social position, nyai's existence itself has a say amongst Madurese women, as they are viewed as an example of piety (De Jonge, 1989: 264). It is the women who have been leading the tarekat (Sufi, a branch of Islamic movement) and its leaders and followers are spread all around Madura, of note are tarekat Qadiriyah wa Naqsabandiyah, tarekat Naqsyabandiyah, and Tijaniyah (Mulyadi, 2015). Nyai has governing authority in moving their people (jamaah) and building pesantren (Islamic boarding school), especially for the advancement of Islam in Madura. Madura community believes that devotion in religion can walk hand in hand with conserving traditional culture (Subaharianto, 2004:75).

Although nyai often is connotated as traditional women; their presence cannot be replaced by another non-formal personage. As Madurese women's religious figure, they are considered as an important person that has to be protected, and their safety is a priority. Madurese women's importance in society is symbolised by land, earth, source of prosperity and fertility. Madurese women become the central pillar of their life sustainability. Thus, their honour has to be protected with life (Subaharianto, 2004). Madura has a matrimonial culture where women have higher rights than men. In Madura tradition, married women live in a house provided by the bride's family, called patobhin (parent's house), made specifically for daughters. Madurese women also are seen as a lineage purification, as in all children born from Madurese mother are Madurese even if their father is not, but not the other way around.

Therefore, with all those cultural symbolic frames, nyai as a female religious leader plays a crucial role in determining the ethnic identity of the people and, at the same time, becomes a significant agency for the social changes and transformation of the society. However, the roles and position of nyai as a (female) leader for the society in Madura have received little attention compared to the male leader both by the formal authorities and the society at large. That is why, this study aims to investigate the existence and the role of nyai, a female leader, in her ways to articulate and contesting their position within the male-dominated culture in Madura Island. This study, thus, focuses on the roles of nyai within the communities and interrogate how nyai has negotiated their existence and space and played with their identity and agency role for the socio-cultural dynamics of the Madurese's women in presentday Indonesia. It is argued that nyai is not only essential to teach communities, particularly the women, but nyai has played a significant role in determining the identity of Madurese women demonstrating evidence of women's liberation in a patriarchal ethnic culture and traditional Islamic adherents. By following two female nyais in Madura in their public activities, this research examines examples of how female leaders are respected, determined, and gained confidence in contesting their persistence and outreach (dakwah) among hundreds of followers, mostly females, in their local place, and outside the Island.

As a woman with an honourable non-academic title, nyai has the knowledge more than any other female in theology. In the pesantren world, 
a nyai is a wife or daughter of kyai or descendants of religious teachers. Nyai Madura has a respected position other than kyai supporter (Hidayati, 2011); they have a massive role in helping kyai in building their religious movement and image making. Generally, a nyai is often seen as a head of the educator in pesantren (Smith, 2014; Srimulyani, 2012), and as a female Islamic character that has specific authority in their community (Kloos, 2016).

The title "nyai" in Madura is always attached to kyai's wife, kyai's descendants and female religious figure that has significant involvement in shaping their society (Julijanti, 2009: 379). Madurese community see nyai as a pious female Muslim, dressed like one reflecting their identity; ${ }^{1}$ their role is significant in religious life placing them as exemplary, especially for Madurese women. As stated above, a nyai is placed as an honourable woman in Madura. An informal interview with a theologist in Pamekasan stated as to how the locals have perceived the notion of a nyai figure from time immemorial until the present times in Madura:

Nyai is a holy woman, thus not every woman can have nyai as her title, because of how huge the responsibility it has. They have to be able to become a good example (uswatun hasanah) for other Madurese women. Usually, nyai is very 'niserran' (loving) to others; they care for their fellows (Interview on 25 October 2017).

This study looks at two nyais in two different sub-region of Madura; they are Nyai Sitti of Sampang and Nyai Dauisy of Sumenep. These two nyais represent as models of high figure female religious leaders and Islamic teachers for women in a patriarchal space. These two nyais have also gained a significant milestone in spreading the teaching of Islam and cultural values to their community. Using qualitative

\footnotetext{
${ }^{1}$ Similar to kyai who wears sarong and cap, nyai's too wear a traditional outfit to reflects her identity. They usually wear clothes following Islamic Sharia law, Sarung bini'(Madurese Batik Sarong) and long veil, which was considered prime fashion style of nyai of yesteryears, but
}

interviews with these two nyais, this study observes their daily activities with the communities like delivering Islamic teachings and dakwah amongst hundreds of local women and the pupils of Islamic boarding school. By following the activities of these two nyais, we understand how these two women leaders have played and negotiated their roles, positions, and women's agency in their communities with the aim of changing people's mind and orientation towards the position of women in a maledominated cultural background. The next section presents the activities of these two Nyais.

\section{The Two Nyais in Women's Theology Room}

In addition to being a teacher in her own female pesantren (boarding school) with more than five hundred pupils ranging from five years to teenagers, Nyai Sitti is involved in various social religious activities. She is involved in raising awareness of living Islamic life by following both traditional ways as well as adapting to an urban lifestyle. Two compelling roles are shaping her authority - internally being pesantren and externally within the community of Madura and outside the Island. Internally, Nyai Sitti can build a negotiation room and control relationships with the male leaders in the pesantren and also in her domestic household life so that it does not confine her role in the pesantren development alone. This has resulted in building a mark for her community. Nyai Sitti is pretty confident and capable of actualising and articulating her knowledge about religion (Islam), especially figh (Islamic prudence) and her understanding of classic theology books that become Madurese references. Her teachings and sayings often become a guide for her community to lead their daily life to the point it merges into tradition.

Nyai Sitti was raised in devout and conservative family background. Her parents too are a religious figure and headmaster in the family's pesantren, where she was born. Little Sitti was

now Sarung bini is gradually being left behind by them. Because of fashion development that also affects Madura, some Madurese nyaii have started wearing gamis (female robe), although not all, since there are nyais who are still loyal to their 'Sarung bini. 
keen on learning, which had driven her to become a high opinionated, knowledgeable, and charismatic woman. In her young age, Nyai Sitti herself pushed her parents to teach her valuable lessons; her curiosity in knowledge is her asset to always learning about her surrounding, making her grow up to be a woman with fantastic capability in understanding Islamic theology books, especially about Islamic rules. During that time, much knowledge that entered Madura was through 'kitab kuning' (traditional Islamic book). Making people understand of kitab kuning became the method of education, especially for the poor and lower class communities.

As a representative of Madurese women, Nyai Sitti reflected her identity as a woman who is brave and tenacious at what she wants and what she believes. Written in history as to how Madurese women fought for themselves no matter what the issue was; this was clearly reflected in Nyai Sitti's interview. At the same time, it is worth noting that Madurese women are also famous for how friendly they are (Raditya, 2014:254).

Even without formal education, Nyai Sitti has broad knowledge about Islamic theology, especially figh and deep understanding of religious books that becomes people's references. Her confidence in making ijtihad (independent reasoning) towards religious and ethical rules leads her to be labelled as "controversial nyai," by the male religious teachers who hold different views from her and even these male leaders had gone to the extent of organising a demonstration in front of her house addressing her as a 'cult' leader. However, her argumentative explanation through the proposition of theology clearly signals that Nyai Sitti is religious authority. Indeed, her ability and deep understanding of kitab kuning have proven

\footnotetext{
${ }^{2}$ Interview with one member of Nyai Sitti's Quran study group in Sampang, Madura.

3 This research does not delve deeply the notion of public/private debate. As per our understanding, the notion of public sphere was first propounded by German philosopher Jürgen Habermas(1962). The notion, public sphere which evolved in the western part of Europe during Renaissance has now been subjected to a larger debate where scholars consider that there is no discrete
}

that women are equals with men in analysing and practising knowledge, even though all these time kitab kuning education was dominated by men. So it is not surprising when someone wants her to give a sermon in their socialreligious event, they have to wait for months.

According to her assistant, what Nyai Sitti has been doing all this time is proving and practising Islamic values to herself, her household, people, organisation, and institutions. Nyai Sitti has her own routine in her daily life, including giving sermons to people from every nook and corner of Madura, even sometimes challenging kyai's activities. $^{2}$

In the constellation of female religious teachers, Nyai Sitti has been shining brightly as someone who is charismatic, knowledgeable, and dominant in her community. Nyai Sitti has significant public $^{3}$ influence that cannot be looked down simply because of how big her followers are in Madura.

Leading a pesantren, Nyai Sitti has been running it well by building a sound system and producing high-quality pupils. Her pesantren is well built, where cleanliness and comfort become a priority. She has also conscientiously constructed a dynamic and harmonious religious environment, making her students feel at home, and continue their education voluntarily. Thus, she has meticulously managed and nurtured her school by catering to all her students' needs.

All these time, women leadership in pesantren continue to witness as an interesting phenomenon. Nyai Sitti utilised nyai's influence on female empowerment, backed up by her ability to lead, broaden her knowledge and to gain people's acknowledgement. During our field study, one of the ustadzahs (teacher) in the pesantren, ${ }^{4}$ who admired the Nyai since she was a child through to her adult commented:

distinction between public and private sphere as both the notions overlap each other (see, Bhattacharyya, $2009 ; 2013 ; 2015 ; 2016)$. In this research, the notion of public is limited to the public influence of the nyais in their surroundings and their religious and spiritual teachings in pesantren and forums.

${ }^{4}$ Her enthusiasm when asked about Nyai Sitti shows that she acknowledges the Nyai's Excellency compared to 
I have been in this pesantren for thirty years, ever since I graduated from the elementary until now, I am a teacher and married with a male teacher in this pesantren. I have seen Nyai Sitti emerging as a great female figure who is tough, brave, and smart. She has inspired us, taught us many things, making us feel at home, and always wants to be close to her.

Sitti's major role in pesantren teaching (morok) is on teaching various theology books. This very fact demonstrates that not all leadership in the pesantren is dominated by the kyai and his male teaching assistants. Moreover, Nyai Sitti has demonstrated a model of wife-husband relationship through negotiating her existence in front of her husband for she has been determined and able to teach her community and become a leader for women not only in Madura but also outside the Island. She has tried to build her husband's trust and find a space for negotiation as a wife and a woman's leader, at the same time, without conflicting her domestic roles and position. Sitti showed determination by allowing her husband to be married to another woman (through the practice of polygamy, which is legal in Indonesia). The logic behind Sitti allowing her husband to practice polygamy is that she had completed her reproductive roles while her husband continues to think of more offspring and another female to look after him. What has been demonstrated by Nyai Sitti in her relationship with her husband has built a space for negotiation to achieve balanced relationship, resulting in neither one of them being in an absolute source of power and authority; this is despite nyai having more roles than kyai (her husband).

Nyai Sitti does not position herself as the second leader in her community. This clearly signals that inequality and subordination of women that usually becomes part of the pesantren tradition do not apply to Nyai Sitti's case. Instead, here it easily materialises gender equality in the pesantren leadership. Blatant proof of Nyai
Sitti's achievement in educating her students is their quality in understanding Islam and interpretation of Quranic verses. Approximately, a thousand female students patiently wait and pay attention to lessons given by the Nyai.

From our interview with one teacher, she was one of Nyai Sitti's former students, shows that Nyai Sitti has a great influence to shape her student's mind and ignite these minds to become influential in the society. In her narration, she stated:

the knowledge I had gained from Nyai Sitti has been applied to the community where I live, and now I am also attributed as nyai. I have also got facilities just like a nyai in my society. It is a blessing that I have gained from Nyai Sitti's knowledge. Her firmness and discipline in teaching us, carved us to become tough women and non-quitter.

Evidently, former students of Sitti, who are spread all around Madura has become influential local leaders for their own community. An honest saying from one of them reveals that the pesantren runs by Nyai Sitti have fame, which has helped her students to gain an important position to transmit Islamic knowledge through a scholarly network in Madura Island. It has been tied and cemented in the relationship between teacher (Nyai Sitti) and students, gaining acknowledgement of theologist position.

Thus, as a guru (teacher), Nyai Sitti is positioned in a high hierarchy in Madurese conformity (Hefni, 2007), where teachers are considered as problem solvers (Rifai, 2007: 373). This further demonstrates that Nyai Sitti has the potential and significant influence in shaping and nurturing social, cultural, political, and especially, religious life. Her role has turned her identity and agency to an essential figure in the community. The closeness between students and other community members with Nyai Sitti is 
formed on strong communication between her and the people around her.

In an esoteric life of Islam in Madura, nyais who live in certain areas are automatically ratified as the authority holders. Through the fatwas (order) they issued or opinion they delivered, nyais become the one whom local people consult with about performing shariah law - this entails regarding everyday worship, seeking for answers in matters of socio-cultural issues dealt with by the locals. Madurese Muslim tend to visit the nyai to consult and ask for advice, before making any decision, or ask guidance in the order they could live well while performing any divine norms. This visit is locally known as "nyabis".

"Nyabis" is a habit of visiting a house of ulama" or teacher in order to get so-called barakah (blessed). This practice is also preferable for the purpose of asking for blessing and prayers of ulama, asking for guidance in making any decision or simply for getting advice. Nyabis is a practice resulting from the Madurese's social construction through the process of objectification in which institutionalisation occurs on the things related to it. The awareness of the importance of ulama and teachers lead to the popularity of nyabis practice mainly before the local people begin any important life activity. The objective of this practice is to find barokah (blessed) through the prayers of ulama, so that the goal of the activity could be achieved with no big obstacles. Madurese people who firmly hold the tradition would feel incomplete and less confidence to begin any bigger activities, such as organising a wedding party or pengajian (Islamic learning forum) before doing 'nyabis'.

Ritual of nyabis for the Madurese usually uses a fine language in expressing the people's wishes to the ulama. People also wear fine and proper Islamic clothes combined with traditional Madurese's fashion. They come to the ulama's place and speak politely and try not to have any eye-contact with the ulama.

In oral communication, people choose the highest/most polite level of local language particularly in communicating the objective of their visit or the life goal they dream of reaching. Meanwhile, in the way they get dressed, they would choose formal and Islamic dress which covers the aurat (private parts) and sometimes combined to the local custom of Madura such as sarung and peci (top head) for men and a long dress with a scarf for women. Likewise, they would also keep the gesture very carefully such as bending down the body, humbly bowing and other polite body languages.

Nyai Sitti's public space is built from her own awareness about her community's real condition, mainly women that were not well educated made them helpless in many situations. Nyai Sitti continues to perform several vital things in combining between religion and the deep-rooted traditions. One of her methods is through the means of Quran study group (Safari).

Nyai Sitti aims to spend a lot of her time and energy wandering from village to village, even going to other cities. Although, the ability and bravery of village women in Madura are still very limited, what Nyai Sitti has been doing to raise female awareness needs to be appreciated by figures who dare to speak out for themselves. The charismatic image she has is not stopping her from forming an idealist-dialogic relationship with her community.

Her room for negotiation with kyais (especially with her own husband) is also built upon her ability as an independent woman in solving a problem and executing it in society, without putting down kyai's position in the middle of patriarchal domination. For Nyai Sitti, awareness and openness about gender equality between men (kyai) and women (nyai) do not have to be through confrontative movement, but through education, dialogue, and discussion. It is what she applies when she plays her role, implicating that kyai gives her full trust and responsibility. Her existence in public space is a manifestation of moral responsibility. The next section discusses the everyday practices of Nyai Dausy.

\section{Negotiating Roles and Position in Public Places}

Nyai Dausy is a pioneer of female empowerment in Sumenep district of Madura. In a town of Sumenep, stands a sizeable pesantren named after her. It bolstered her position as a pioneer of female empowerment as the place become a 
symbol of female equality in the pesantren world construction of Madura Island.

According to Nyai Dausy, the reason for using her own name in the school is a form of motivation for women, with hopes that they will play an active role and be useful for their society, making women's names carved in history. Indeed, Nyai Dausy launched an anti-mainstream movement, as the norm was naming a pesantren after a kyai as husband, father, or grandfather. In Sumenep, Nyai Dausy is the only woman who established and ran a pesantren, which commonly the male kyai owns it.

Islamic community of Madura generally knows patriarchal leadership, where kyai's role is very dominant in pesantren, whereas Nyai Dausy becomes an interesting phenomenon as she is a woman that can be a dominant figure in the pesantren's leadership network (Qibtiyah, 2014). Nyai Dausy as a central leader in her pesantren started her authority through a religious organisation like Nahdatul Ulama, mobile Quran study forums, and forums of the Islamic economy. She has not only established and developed pesantren, but also some private academy for all level including higher education level, called STITA, as well as initiated in forming various businesses ranging from Sumenep batik, Madurese traditional herbals, perfumes, and others in order to empower and support the incomes of her community.

Her tenancy and persistence in developing informal and small scale business sectors making her pesantren have widely become well-known. Nyai Dausy dreams of contributing to her community, especially in human resource development. For Nyai Dausy, if a woman is empowered, she will not be in a subordinate position, and there will be no comprehensive source of power and authority in life, "be it in pesantren, or in the society;" this was revealed in a personal interview with Nyai Dausy .

In running her pesantren, Nyai Dausy is known for her generosity, as she does not take any tuition fee from her pupils. Her principle is

\footnotetext{
${ }^{5}$ Child marriage persists in Madura, especially amongst villagers and remote communities with very pragmatic goal in order to lessen family's financial burden. This
}

always to do charity and not give burden to the pupils' parents who want to send their children to study in the pesantren. In her interview, she explained how the pesantren was established:

The students are mostly coming from poor families. I scouted kids from villages, asking them to go to pesantren for free. I do that so they will not feel a financial burden. All they need is passion and will to learn; otherwise, they will not go to school. I do not want low-income families' children to grow up uneducated and become a slave in their own country. They are poor because they do not know, and knowledge is the key to getting out of poverty in the future. Running a pesantren means spending time, energy, and thoughts, willing to go to the field, see the condition of your students and people around, especially those in remote areas. The pesantren is funded from my own business and donations from publics.

Nyai Dausy is known as someone who is energetic, a little peculiar, and full of spirit. She is willing to be hands-on, teaching people in remote areas, and active doing social works and protection activities for women. As an independent woman with high mobility, she gained nyai title not only by blood (as her father is a well-known great kyai in Sumenep district), but for her willingness to fight in the name of religion (Islam). For her, the main asset to be a prominent woman is a readiness to breaching tradition that restrained her potential in moving forward.

Nyai Dausy commits to guarding her school's "garden." What she means by her "garden" is her "flowers and leaves," as she symbolised her female students (locally termed as binderi) as flowers and her male students (locally termed as bindere) as leaves. As she is trusted by the parents; so she is committed to disallowing child marriage under her watch. ${ }^{5}$

finding is similar to the finding as reported by Bhattacharyya and Singh (2018) in their research on abandoned widows of Varanasi, where in India too, the 
One of the reasons she builds her pesantren was her concern on the low-income families in Madura who have limited access to education because of the high costs that the parents cannot afford to pay. A local culture worsens the condition that put aside education, especially for daughters (girls), as they are viewed to be domestic helpers who do not need high education. The underlying assumption is that female dignity lies in her obedience to her husband.

It becomes Nyai Dausy's primary motivation in fighting for her students' education, emphasising on their skills. For her, children are nation's most precious asset, and God and their parents trust them to her, and she has to protect and nurture them as good as possible, forge them to become competent and skilful human resources.

The Nyai teaches her students various skills, from making batik, embroidery, even potion making, conserving traditional Madurese cultures. Many of her students are now prominent players in the business market.

Despite a handful things in her agenda as the pesantren leader, Nyai Dausy still have time to commit towards the even broader scope of community's life. She has what is called linuwih (advantages), where people come to visit and meet her from entire Madura, from Java, even from other islands in Indonesia to seek for her blessing and her ability to cure particular illness and severe. In her account, Nyai Dausy said that it is not easy to gain those "advantages" in her now, as she has to do a series of rituals ever since she was a little girl. In one of the rituals, she consistently abstained herself from eating rice and only fed herself on certain flowers. However, this is only one ritual, but she had to undergo many other similar rigorous rituals to

practice of child marriage continues in many regions, which is illegal in the eyes of law.

${ }^{6}$ When we were conducting the research, we visited Nyai Dausy's house to meet her face to face. We could not met her immediately, as she had many guests. Many men and women from near and far came with their own problems. This made our task a little easy for us to randomly ask people about what had motivated them to come and see attain her position which she was unwilling to disclose. ${ }^{6}$

Aside from meeting her clients, her days also filled with giving sermons that have been scheduled. Nyai Dausy controls about 20 groups of women's sermon forums entire the Island. She is also invited to deliver a sermon outside her own sermon forums. Her public role shows her ability to build a certain charisma within the community.

The Nyai's image is also imprinted on her students, as she becomes their inspiration figure in their way of thinking and behaving. The way Nyai Dausy views life becomes a benchmark for them, as they idealised her by making her as a role model. As one of her senior students, who is now an administrator in pesantren commented:

For me, Nyai Dausy is a quirky woman. Her knowledge makes her sacred. We heard stories from older adults as to how she meticulously followed her father's footsteps who had practised supranatural practice. Nyai Dausy is an amazing nyai, as she never formally went to school yet she is fluent in English, has deep insight, and teaches us a foreign language. Her Quran study forums are scattered in the villages. The important thing we need to follow is her persistence in studying and her confidence. Her fight to raise women's dignity is incredible, one thing that she always emphasised on us is how we as women cannot stay still and become a cry baby. ${ }^{7}$

The doctrine that is always stressed by Nyai Dausy to her students is that there is no time to rest, triggered the students to be involved in various activities and programs in the pesantren. Meeting face to face with Nyai Dausy, the first impression she gave was her spirited self. It was formed by her subjective experiences, focusing

Nyai Dausy, as well as gain a glimpse of their trust towards her ability. The problems they brought in ranged from household/domestic problems, community disruptions, and health problems.

${ }^{7}$ Interview with an administrator of Pondok Pesantren Putri 
on thankfulness of her life, configures her motivation and power to push and direct her students and people.

The relation pattern in Nyai Dausy's family is very unusual. When her husband was still alive, he chose to focus on ritual and domestic things, making him trusted a lot of public affairs towards her. She recalled that her husband was "praying a lot at home, pray for my success outside, but I never looked down on him. I am still respecting him."

For Nyai Dausy, gender equality is a form of women's empowerment. If women are smart and skillful, equality automatically arrives. So, there will be no scope for debate. Instead, she believes that women's empowerment should be starting in education because knowledge can create some form of power. Indeed, her braveness taking roles and initiating female economic development is a form of how equality can be reached without raising war (with the males).

As a female religious figure, Nyai Dausy has proven that a woman leader can be equal with male religious figures by doing various human resource development, building independent characteristic, and forming a harmonious society. Her leadership in the pesantren has shown awareness about gender equality in the male-dominated society that places the position of women subordinate from the men.

\section{Conclusion}

This research set out to examine the roles and position of female religious leaders in Madura Island, known as nyai Madura. The two nyaisNyai Sitti and Nyai Dausy in Madurese nyai typology are categorised as "Nyai rajheh" (great nyais). In the context of the nyai hierarchical position in Madura, nyai rajheh commands authority, thereby accomplishes positions on her social class. Amongst all nyais, nyai rajheh is the central figure, where their popularity are shaped by their personal charismatic roles, genealogy, and the people's power. The dominant indicator for nyai rajheh is about having a successful pesantren and many Quran reciting forums, where nyai rajheh teaches students and followers. Nyai rajheh is placed as a top figure, whatever the nyai says and performs becomes a benchmark for the community, especially the women.

In general, Madurese women have positioned the nyais as their motivator, as an inspiration, as a mood booster and great support in their everyday practices. In other words, in socioreligious construction, Nyai Sitti and Nyai Dausy are a representation of the Madurese religious teachers and leaders. Their existence is energy and social spirit for the community and essential for balancing and guiding religious-based life.

Indeed, these two nyais exemplify Madurese female leaders who have become a source of women's pride and dignity and a source of spirit. Although this research has been able to discuss only two nyais, it serves a basis for further indepth research on nyais of Indonesia, perhaps, from a feminist perspective as it is commonly perceived that long before feminism became a topic of discussion in Indonesia, the people of Madura had already placed women leaders in equal position to that of their male counterparts.

\section{References}

Bhattacharyya, R. (2009). Examining the changing status and role of middle class Assamese women: Lessons from the lives of university students, PhD thesis. Newcastle University, UK.

Bhattacharyya, R. (2013). Are We Empowered? Stories of young Indian working women, Saarbrücken, Germany: Lap Lambert Academic Publishing, (ISBN: 978-3-65920580-4)

Bhattacharyya, R. (2015). Understanding the Spatialities of Sexual Assault against Indian women in India, Journal Gender, Place and Culture: A Journal of Feminist Geography, 22(9), 1340-1356 DOI: 10.1080/0966369X.2014.969684

Bhattacharyya, R. (2016). Street Violence against Indian Women in India: Mapping Prevention Strategies, Asian Social Work and Policy Review, 10 (3), 311-325, DOI: 10.1111/aswp.12099 
Bhattacharyya, R. and Singh, S. (2018), Exclusion (and seclusion): Geographies of Disowned Widows of India, GeoJournal, 83 (4), 757-774, DOI: 10.1007/s10708-0179800-0

De Jonge, H, (1989). Madura Dalam Empat Zaman: pedagang, perkembangan ekonomi, dan Islam, Jakarta: Gramedia

Habermas, J. (1962 trans 1989). The Structural Transformation of the Public Sphere: An Inquiry into a category of Bourgeois Society, Polity, Cambridge.

Hefni, M. (2007). BHUPPA'-BHÂBHU'-GHURURATO: Studi Konstruktivisme-Strukturalis tentang Hierarkhi Kepatuhan dalam Budaya Masyarakat Madura, KARSA, XI(1).

Hidayati, T. (2011). Nyai Madura: studi hubungan patron klien perempuan Madura setelah keruntuhan orde baru (1988-2008), Unpublished dissertation, UIN Sunan Kalijaga Yogyakarta.

Julijanti, D. (2009). Potret Nyai Salimah Hadi sebagai Pemimpin Publik di Madura, dalam Gender and Politik, Yogyakarta: Tiara Wacana

Kloos, D. (2016). The Salience of Gender: Female Islamic Authority in Aceh, Indonesia, Asian Studies Review, 40(4), 527-544 http://dx.doi.org/10.1080/10357823.2016.1 225669

Kuntowijoyo (1998). Perubahan social dalam masyarakat agraris: Madura 1850-1940, Yogyakarta: PAU Studi Sosial UGM
Ma'arif, S. (2015). The History Of Madura: sejarah panjang Madura dari kerajaan, kolonialisme samapai kemerdekaan, Yogyakarta: Araska

Mulyadi, A. (2015). Budaya Egalitarianisme Perempuan Madura Dalam Tarekat Naqsyabandiyah, KARSA, 23(1)

Qibtiyah, M. (2014). Kepemimpinan Perempuan: Peran Perempuan Dalam Jejaring Kekuasaan Di Pondok Pesantren Aqidah Usymuni Terate Pandian Sumenep. Unpublished Disertasion, UIN Sunan Ampel Surabaya.

Raditya, A, (2014). Sosiologi Tubuh, membentang teori di ranah aplikasi, Yogyakarta: Kaukaba Dipantara

Rifai, M. (2007). Manusia Madura: pembawaan, perilaku, etos kerja, penampilan dan pandangan hidupnya, seperti dicitrakan peribahasanya, Yogyakarta: Pilar Media

Smith, B. and Woodward, M.(2014).Gender and Power in Indonesian Islam, Leaders, feminists, Sufis and pesantren selves, London and New York: Routledge

Srimulyani, E. (2012). Woman from traditional islamic educational institutions in indonesia: negotiating public spaces, Amsterdam: Amsterdam University Press,

Subaharianto, A. (2004). Tantangan Industrialisasi Madura: Membentur kultur, Menjunjung leluhur, Malang, Banyumedia Publishing 